\title{
Regulation of pancreatic $\beta$-cell mass and proliferation by SOCS-3
}

\author{
K Lindberg1*, S G Rønn $^{1,3 *}$, D Tornehave², H Richter ${ }^{1}$, J A Hansen ${ }^{1}$, J Rømer², \\ M Jackerott ${ }^{4}$ and $\mathrm{N}$ Billestrup ${ }^{1,3}$ \\ ${ }^{1}$ Department of Signal Transduction, ${ }^{2}$ Department of Pharmacology, Novo Nordisk A/S, Bagsværd, Denmark \\ ${ }^{3}$ Steno Diabetes Center, Niels Steensens Vej 6, DK-2820 Gentofte, Denmark \\ ${ }^{4}$ Institute of Medical Biochemistry and Genetics, Panum Institute, University of Copenhagen, Denmark
}

(Requests for offprints should be addressed to N Billestrup at Steno Diabetes Center, Gentofte, Denmark; Email: nbil@steno.dk)

*(K Lindberg and S G Ronn contributed equally to this paper)

(Present address of J Rømer is: Finsen Laboratory, Rigshospitalet, Denmark)

\begin{abstract}
Growth hormone and prolactin are important growth factors for pancreatic $\beta$-cells. The effects exerted by these hormones on proliferation and on insulin synthesis and secretion in $\beta$-cells are largely mediated through the Janus kinase (JAK)/signal transducer and activator of transcription (STAT) signaling pathway. Suppressors of cytokine signaling (SOCS) proteins are specific inhibitors of the JAK/STAT pathway acting through a negative-feedback loop. To investigate in vivo effects of SOCS-3 in growth hormone $(\mathrm{GH})$ /prolactin signaling in $\beta$-cells we generated transgenic mice with $\beta$-cell-specific overexpression of SOCS-3. The relative $\beta$-cell proliferation and volume in the mice were measured by morphometry. $\beta$-Cell volume of transgenic female mice was reduced by over $30 \%$ compared with $\beta$-cell volume in wild-type female mice. Stimulation of transgenic islets in vitro with $\mathrm{GH}$ showed a reduced tyrosine phosphorylation of STAT-5 when compared with wild-type islets. Transduction of primary islet cultures with adenoviruses expressing various SOCS proteins followed by stimulation with GH or glucagon-like peptide-1 (GLP-1) revealed that SOCS-3 inhibited GH- but not GLP-1-mediated islet cell proliferation, indicating that the decreased $\beta$-cell volume observed in female transgenic mice could be caused by an inhibition of $\mathrm{GH}$-induced $\beta$-cell proliferation by SOCS-3. In spite of the reduced $\beta$-cell volume the transgenic female mice exhibited enhanced glucose tolerance compared with wild-type littermates following an oral glucose-tolerance test. Together these data suggest that SOCS-3 modulates cytokine signaling in pancreatic $\beta$-cells and therefore potentially could be a candidate target for development of new treatment strategies for diabetes.
\end{abstract}

Journal of Molecular Endocrinology (2005) 35, 231-243

\section{Introduction}

Understanding the molecular mechanisms involved in pancreatic $\beta$-cell growth and differentiation is fundamental for developing novel strategies for the prevention and treatment of diabetes. This is the case for both type 1 and type 2 diabetes where the former results from the autoimmune destruction of the $\beta$-cells while the latter is caused by $\beta$-cell failure due to insulin resistance.

Growth hormone (GH), prolactin (PRL) and placental lactogen (PL) have been shown to be important growth factors for the $\beta$-cell as they stimulate insulin synthesis as well as $\beta$-cell proliferation (Nielsen 1982, 1985, Nielsen et al. 1992, Brelje et al. 1993). Specific receptors for both PRL and GH are present on $\beta$-cells and the expression level of these receptors is regulated when expansion of the $\beta$-cell mass is seen, for example during development and pregnancy (Sorenson \& Brelje 1997). The importance of PRL for development and maintenance of the $\beta$-cell mass is demonstrated in mice deficient in the PRL receptor. These mice have a smaller $\beta$-cell mass and lower insulin mRNA and insulin content as well as blunted insulin secretion in response to glucose stimulation when compared with their wild-type littermates (Freemark et al. 2002). In contrast, transgenic mice overexpressing PL in their $\beta$-cells exhibit $\beta$-cell hyperplasia, elevated pancreatic insulin content and plasma insulin, and are prone to develop hypoglycemia (Vasavada et al. 2000).

GH and PRL exert their signals in the $\beta$-cell through binding to the GH and PRL receptors. Subsequently, different intracellular signaling pathways including Janus kinase $(\mathrm{JAK}) /$ signal transducer and activator of transcription (STAT), $\mathrm{Ca}^{2+}$ and mitogen-activated protein kinases are activated in the cell (Argetsinger \& Carter-Su 1996). Among these, the JAK/STAT pathway is the best characterized and in particular JAK-2 and STAT-5 seem to be important (Chow et al. 1996, Smit et al. 1996, 
Galsgaard et al. 2001). Notably, it has been found that STAT-5 activity is essential for GH-induced insulin gene transcription and for $\beta$-cell proliferation (Galsgaard et al. 1996, Friedrichsen et al. 2001, 2003).

The identity of the signaling pathways induced by PRL and GH in the $\beta$-cell is reasonably well understood; however, only a few studies have addressed the down-regulation of these pathways despite this issue also being essential for understanding regulation of $\beta$-cell growth and differentiation. The suppressors of cytokine signaling (SOCS) proteins have turned out to be critical negative regulators of signaling induced by various cytokines, including GH and PRL (Adams et al. 1998, Pezet et al. 1999, Ram \& Waxman 1999, Tomic et al. 1999). The basal level of SOCS expression in cells is generally very low but is induced in a transient manner upon cytokine stimulation both in vitro and in vivo. The cytokine induced SOCS expression is STAT-dependent, and as the SOCS proteins - once induced - act to down-regulate cytokine signaling, they appear to work in a classical negative-feedback loop (Endo et al. 1997, Naka et al. 1997, Starr et al. 1997). However, several studies also suggest that crosstalk between different cytokine-induced signaling pathways can be mediated by the SOCS proteins (Magrangeas et al. 2001, Schmitz et al. 2000, Wu et al. 2003).

We have shown previously that SOCS-3 is able to inhibit GH-induced insulin production and proliferation of $\beta$-cell lines in vitro (Rønn et al. 2002). However, to fully understand the role of SOCS-3 in $\beta$-cell growth and differentiation, analysis of the SOCS-3 effect in more physiologically relevant systems are of great importance. The present study was carried out to elucidate whether the SOCS proteins, and in particular SOCS-3, can influence cytokine-mediated signaling in pancreatic $\beta$-cells by means of two different approaches, namely transgenic mice with $\beta$-cell-specific SOCS-3 overexpression and adenoviral-mediated overexpression of SOCS proteins in primary $\beta$-cells grown as a monolayer.

\section{Materials and methods}

\section{Generation of the RIP-SOCS-3 DNA construct}

The RIP-SOCS-3 construct was made by modifying the mammalian expression vector, pCI (Promega). The cytomegalovirus immediate early enhancer/promoter was replaced with a $600 \mathrm{bp}$ HindIII-NdeI fragment from the pOK1 vector (Karlsson et al. 1987) containing 410 bp of rat insulin I gene 5' flanking DNA (RIP). In addition, a $730 \mathrm{bp}$ XbaI fragment from the pEF-BOS vector (Starr et al. 1997), containing $715 \mathrm{bp}$ of N-terminal FLAG-epitope-tagged full-length SOCS-3 cDNA (SOCS-3), was inserted at the XbaI site. The RIP-SOCS-3 part of the plasmid was excised with AlwNI and ClaI and purified by conventional gel- extraction and ethanol-precipitation methods. Transgenic RIP-SOCS-3 C57Bl/6J/DBA/J mice were generated by Dr Peter Hjort at the Institute of Molecular and Structural Biology at University of Aarhus, Denmark.

\section{Stabling and breeding}

All animal experiments carried out in this project have been approved by Dyreforsøgstilsynet, the Danish Animal Experiments Inspectorate. Potential founders were transferred to the breeding facility of $\mathrm{M} \& \mathrm{~B} \mathrm{~A} / \mathrm{S}$, Ry, Denmark. At this facility, by backcrossing with wild-type $\mathrm{C} 57 \mathrm{Bl} / 6 \mathrm{~J}$ mice, all further breeding of these animals was carried out under directions from our laboratory. The mice were housed with free access to food and water.

\section{Preparation of tissue for in situ hybridization and immunohistochemistry}

Immediately after removal from the animal, tissue was placed in 4\% formalin, $\mathrm{pH} 7 \cdot 4$ (Bie \& Berntsen, Rødovre, Denmark), and fixed for 1-3 days, after which the tissue was dehydrated in increasing concentrations of ethanol, finishing with Estisol 220 (Esti Chem, Køge, Denmark), and embedded in paraffin. Tissue sections of $3 \mu \mathrm{m}$ were cut on a Leica 2055 Autocut microtome and stored under dust- and RNase-free conditions until use.

\section{In situ hybridization}

A 730 bp XbaI fragment from the pEF-BOS vector (Starr et al. 1997) containing $715 \mathrm{bp}$ of N-terminal FLAG-epitope-tagged full-length SOCS-3 cDNA (SOCS-3) was cloned into the pGEM vector (Promega). RNA probes were made with an RNA Transcription kit (Stratagene) and $\left.{ }^{35} \mathrm{~S}\right] \mathrm{UTP}$ (Amersham Biosciences) after digestion with either HindIII (SOCS-3 antisense probes) or KpnI (SOCS-3 sense probes) followed by in vitro transcription with either T7 RNA polymerase (SOCS-3 antisense probes) or SP6 RNA polymerase (SOCS-3 sense probes). Following hydrolysis and precipitation, the probes were resuspended in hybridization buffer preheated to $37^{\circ} \mathrm{C}$ (final concentrations after addition of probes: $1 \times$ SALTS $(0.3 \mathrm{M} \mathrm{NaCl}$, $10 \mathrm{mM}$ Tris/HCl, $10 \mathrm{mM} \mathrm{NaPO}$ (pH 6.8), $5 \mathrm{mM}$ EDTA, $0.02 \%$ (w/v) Ficoll 400 (Sigma) and 0.02\% (w/v) PVP-40 (40 000 Da; Sigma), 0.02\% (w/v) BSA fraction $\mathrm{V}$ (Sigma) in diethyl pyrocarbonate-treated water), 4\% deionized formamide (Fluka), 1\% dextran sulphate (Sigma), $1 \mathrm{mg} / \mathrm{ml}$ tRNA (from RNA Transcription kit) and $8 \mathrm{mM}$ dithiothreitol). Then the final probe mixtures were placed on proteinase K-digested, acetylated and dehydrated tissue sections, which were then covered with coverslips and incubated at $47^{\circ} \mathrm{C}$ in a humidified chamber overnight. Following stringent 
washes, tissue sections were dehydrated in increasing concentrations of ethanol with $300 \mathrm{mM}$ ammonium acetate, air-dried and covered with an autoradiography emulsion (50\% Ilford K5 emulsion (Ilford) and $1 \%$ glycerol in MilliQ water) and exposed in the dark at $4{ }^{\circ} \mathrm{C}$ for 3 weeks. Then sections were developed with Kodak D19 developer according to the manufacturer's instructions and counterstained with hematoxylin and eosin before they were evaluated under a microscope.

\section{Immunohistochemistry}

Tissue sections were de-paraffinized in $2 \times 10$ min xylene and rehydrated with decreasing concentrations of ethanol. Sections were treated with $0.5 \% \mathrm{H}_{2} \mathrm{O}_{2}$ for $20 \mathrm{~min}$ to block endogenous peroxidase activity. Heat-induced epitope retrieval (HIER) was performed in a microwave oven in Tris/EGTA buffer, $\mathrm{pH} 9 \cdot 0$, followed by cooling in the same buffer in a water bath with running water for $15 \mathrm{~min}$. Inhibition of endogenous biotin was performed with a Biotin-Blocking System (DakoCytomation) according to the manufacturer's instructions. Triple fluorescence-labeled sections were incubated overnight at $4{ }^{\circ} \mathrm{C}$ with anti-SOCS-3 antibodies (Go- $\alpha$-Socs3, 1:2000; M-20, sc-7009; Santa Cruz Biotechnology) followed by visualization with a tyramide amplification system (TSA IMI) Biotin System; Perkin Elmer) according to the manufacturer's instructions except that a last incubation with StrepAvidin-conjugated horseradish peroxidase and diaminobenzidine was exchanged with an incubation with Texas Red-conjugated StreptAvidin (1:100; Amersham Biosciences) for $30 \mathrm{~min}$. Then sections were incubated for $1 \mathrm{~h}$ at room temperature with anti-insulin antibodies (guinea-pig $\alpha$-insulin, 1:1000; 651041; ICN). Insulin-labeled cells were visualized with FITC-labeled secondary antibodies (FITC-Ra- $\alpha$-Gui, 1:40; F0233; DakoCytomation). Following this, sections were incubated for $1 \mathrm{~h}$ at room temperature with a cocktail of antibodies against non- $\beta$-cell hormones (Mo- $\alpha$-glucagon, 1:800; Mo- $\alpha$-somatostatin, 1:400 (both from Novo Nordisk), and Ra- $\alpha$-pancreatic polypeptide, 1:1000; A0619; DakoCytomation). Cells labeled with antibodies against non- $\beta$-cell hormones were visualized with 7amino-4 methylcoumarin-3 acetic acid (AMCA)-labeled secondary antibodies (AMCA-Go- $\alpha-M o, 1: 100 ; 115-$ 155-146, and AMCA-Go- $\alpha-R a, 1: 100 ; 111-155-146$ (both from Jackson Immunoresearch Laboratories)) before sections were mounted in DAKO ${ }^{\circledR}$ Flourescent Mounting Medium (DakoCytomation) and evaluated in a fluorescence microscope. Anti-insulin/antibromodeoxyuridine (BrdU; guinea-pig $\alpha$-insulin, 1:1000/ Mo- $\alpha$-BrdU, 1:100; M0744; DakoCytomation) double chromogen labeling for morphometric measurements were performed on a DAKO ${ }^{\circledR}$ Autostainer (DakoCytomation) according to the manufacturer's instructions. Sections were incubated with HRP-Ra- $\alpha$-Gui, 1:100 (where HRP is horseradish peroxidase; P0141; DakoCytomation) and Biot-Do- $\alpha-M o, ~ 1: 1000$ (715-065-150; Jackson) secondary antibodies. Insulin-labeled cells were visualized with Nova Red (Vector Laboratories, Burlingame, CA, USA) according to the manufacturer's instructions and BrdU-labeled cells were visualized with diaminobenzidine/nickel $(0.5 \mathrm{mg} / \mathrm{ml}$ diaminobenzidine (Sigma), $0 \cdot 2 \%$ nickel ammonium sulphate and $0 \cdot 1 \%$ $\mathrm{H}_{2} \mathrm{O}_{2}$ ). Sections were counterstained in hematoxylin, dehydrated in increasing concentrations of ethanol and xylene, mounted in Pertex (Histolab Products AB) and evaluated under a microscope.

\section{Blood glucose and body weight}

Blood glucose in mice was measured in a drop of tail blood in a Glucometer Elite ${ }^{\circledR}$ (Bayer) after 6 h fasting once a week between the ages of 4 and 25 weeks. Mice were weighed on a laboratory scale (BL1500; Sartorius) once a week, also between the ages of 4 and 25 weeks.

\section{Pancreatic insulin content}

The entire pancreas from mice was weighed, sonicated in $1 \mathrm{ml} 3 \mathrm{M}$ acetic acid and stored at $-20^{\circ} \mathrm{C}$. Each pancreas was extracted by vigorous shaking for $2 \mathrm{~h}$ at room temperature followed by centrifugation. The supernatant was recovered, and $1.6 \mathrm{ml} 3 \mathrm{M}$ acetic acid was added to the pellet. The extraction and centrifugation procedures were repeated and the supernatants were pooled. The homogenates were diluted in $0.04 \mathrm{M}$ sodium phosphate buffer/0 $1 \mathrm{M} \mathrm{NaCl}, \mathrm{pH} 7 \cdot 4$. Insulin content was determined by RIA using guinea-pig anti-insulin serum, mono-iodinated human insulin as tracer, rat insulin as standard, and ethanol to separate antibody-bound insulin from free insulin (BonnevieNielsen 1980).

\section{Plasma insulin}

Plasma insulin concentrations were determined using a rat insulin RIA kit (Linco Research, St Charles, MO, USA).

\section{Oral glucose-tolerance test}

An oral glucose-tolerance test was performed on six male and six female wild-type mice and on six male and six female RIP-SOCS-3 mice at an age of 5-7 weeks. A $50 \%$ glucose solution $(2 \mathrm{~g} / \mathrm{kg}$ body weight $)$ or an equivalent volume of water was administered orally. A blood sample $(5 \mu \mathrm{l})$ was taken from the tail vein before $(t=0)$ and at 10, 20, 30, 40 50, 60, 90 and 120 min after glucose/water administration and dissolved in $250 \mu \mathrm{l}$ $\mathrm{EBIO}^{\circledR}$ buffer (Eppendorf). Blood glucose was measured on a Glucose Analyzer EBIO ${ }^{\circledR}$ (Eppendorf) according to the manufacturer's instructions. 


\section{Point-counting morphometry}

Point-counting morphometry were performed on pancreatic sections randomly selected after the smooth fractionation method. Pancreata from six male and six female wild-type mice as well as pancreata from six male and six female RIP-SOCS-3 mice, that had received $\operatorname{BrdU}(0.8 \mathrm{mg} / \mathrm{ml})$ in the drinking water the night before they were killed, were removed, fixated and paraffinembedded as described in the section on preparation of tissue for in situ hybridization and immunohistochemistry, above. From every pancreas, sections of $3 \mu \mathrm{m}$ were collected every $200 \mu \mathrm{m}$ throughout the whole organ. From a randomization table it was decided which section number was to be sampled first from a pancreas. A section from each of the sampled levels was double-stained against insulin and $\mathrm{BrdU}$ and $25 \%$ of the area of a section from every second level was scored for area of pancreatic tissue, area of $\beta$-cells and number of $\beta$-cell nuclei using an Olympus BX-50 microscope (Olympus Denmark A/S, Ballerup, Denmark) fitted with video camera and monitor, a PC-controlled motorized stage and the Cast-Grid version 2·0 software (Olympus Denmark A/S), which randomly selected areas for analysis in total amounting to $25 \%$ of the section. BrdU-positive $\beta$-cell nuclei were counted on the whole section area. A randomization table was used to decide whether the section from the first or second level should be the first section to be scored. After all raw data had been collected, pancreatic volume, $\beta$-cell volume, number of $\beta$-cell nuclei and numbers of BrdU-positive (proliferating) $\beta$-cell nuclei were estimated per pancreas and the average value of $\beta$-cell volume as a percentage, as well as the average percentage of proliferating $\beta$-cells per group, were calculated.

\section{Adenoviral constructs}

Generation of the adenoviral constructs were based on the AdEasy kit from Q-BIOgene (AES1000B; Carlsbad, CA, USA) according to the manufacturer's instructions. In short, mouse SOCS-3 cDNA was subcloned into the multiple cloning site of the pShuttle-cytomegalovirus transfer vector via an XbaI site. Subsequently, $1 \mu \mathrm{g}$ recombinant PmeI-linearized pShuttle-cytomegalovirus was co-transfected into the electro-competent Escherichia coli strain BJ5183 with $200 \mathrm{ng} \operatorname{Ad} 5 \Delta \mathrm{E} 1 / \Delta \mathrm{E} 3$ (the viral genome) to allow homologous recombination. Positive recombinants were identified by size of the plasmid and digestion with $\mathrm{PacI}$ and subsequently transformed into DH5 $\alpha$ cells to amplify the recombinant viral DNA. The recombinant adenoviral construct was linearized with PacI and $5 \mu \mathrm{g}$ were transfected into HEK-293A cells. After viral plaque formation, small-scale virus amplification was performed and recombinant viruses were screened by western-blot analysis. Large-scale formation was performed and recombinant viruses were purified on $\mathrm{CsCl}$ gradients. Virus titers were measured at OD $260 \mathrm{~nm}$.

\section{Western blotting}

Islets from adult ( $>10$ weeks old) transgenic mice or their non-transgenic littermates were isolated. Following isolation, islets were cultured for 5-7 days in RPMI 1640 glutamax-1 (Gibco-BRL) supplemented with 10\% foetal bovine serum (Clontech) and 1\% penicillin/ streptomycin (Gibco-BRL) in $5 \% \mathrm{CO}_{2}$ at $37^{\circ} \mathrm{C}$. After culture 200 islets/condition were cultured in $200 \mu \mathrm{l}$ RPMI 1640 glutamax-1 with $0 \cdot 5 \%$ human serum and $1 \%$ penicillin/streptomycin in the absence or presence of $0.5 \mu \mathrm{g} / \mathrm{ml}$ human $\mathrm{GH}(\mathrm{hGH})$ for $20 \mathrm{~min}$. Subsequently islets were lysed for $1 \mathrm{~h}$ in ice-cold lysis buffer (20 mM Tris, pH 7.0, 0.27 M sucrose, $1 \mathrm{mM}$ EDTA, $1 \mathrm{mM}$ EGTA, $50 \mathrm{mM}$ NaF, $1 \%$ Triton-X-100, $5 \mathrm{mM}$ tetrasodium pyrophosphate, $10 \mathrm{mM}$ glycerolphosphate, $1 \mathrm{mM}$ benzamidine, $4 \mu \mathrm{g} / \mathrm{ml}$ leupeptin, $1 \mathrm{mM}$ dithiothreitol and $1 \mathrm{mM} \mathrm{NaVO}$ ). Lysates were centrifuged for $5 \mathrm{~min}$ at $15000 \boldsymbol{g}$ and $7.5 \mu \mathrm{g}$ protein/sample were subjected to SDS/PAGE and western blotting using the NuPAGE protocol (Invitrogen). Protein was detected using an antibody recognizing tyrosine-phosphorylated STAT-5 (catalog no. 9351; Cell Signalling) and upon stripping the same membranes were subjected to an antibody recognizing total STAT-5 (sc-835; Santa Cruz Biotechnology). Blots were developed using LumiGlo (Cell Signalling) and analysed by means of Image Gauge from Fujifilm.

\section{$\beta$-Cell proliferation assay}

Primary $\beta$-cell cultures were prepared from islets isolated from 3-5-day-old rats as described by Nielsen et al. (1989). The titer of adenovirus used for islet cell transduction was determined by transduction of islet monolayer cells with increasing amounts of SOCS-3 expressing adenovirus followed by immunostaining for SOCS-3. Transduction using $5 \times 10^{8} \mathrm{pfu} / \mathrm{ml}$ resulted in expression of SOCS- 3 in more than $80 \%$ of the $\beta$-cells and this concentration of virus was used for analysis of $\beta$-cell proliferation. The cultures were washed and starved in RPMI containing $2 \%$ human serum. The next day cultures were transduced with adenovirus and after $24 \mathrm{~h}$ stimulated with $\mathrm{GH}(0.5 \mu \mathrm{g} / \mathrm{ml})$ or glucagon like peptide-1 (GLP-1) (100 nM). Following an additional $24 \mathrm{~h}, \operatorname{BrdU}(10 \mu \mathrm{M})$ was added to the cultures and after $20 \mathrm{~h}$ the cultures were fixed in 1\% paraformaldehyde and stained for insulin and BrdU as described previously (Nielsen et al. 1989). The proliferation of $\beta$-cells was determined by counting 1000-1500 $\beta$-cells and calculating the fraction of these positive for BrdU staining. 


\section{Statistical testing}

Nominal data were tested with the Student's $t$-test and ordinal data were tested with the Wilcoxon two-sample test. For both tests $P \leq 0 \cdot 05$ was used as the lowest level for the presence of a significant difference.

\section{Results}

\section{SOCS-3 is expressed specifically in the $\beta$-cells of transgenic mice harboring the SOCS-3 gene under the control of the rat insulin promoter}

Transgenic mice expressing the SOCS-3 gene under the transcriptional control of $410 \mathrm{bp}$ of rat insulin 1 gene $5^{\prime}$ flanking DNA (RIP; Karlsson et al. 1987) were generated. Two lines of mice exhibiting $\beta$-cell-specific overexpression of the SOCS-3 gene were obtained (line 7 and line 15).

At the RNA level, in situ hybridization using an antisense probe specific for SOCS-3 mRNA revealed a positive hybridization signal in islet cells of transgenic mice. As can be seen in Fig. 1A and B, heterogenous levels of SOCS-3 mRNA expression were observed in the individual islet cells (shown for line 15 in Fig. 1). Few cells showed very high expression levels whereas most islet cells showed more moderate levels of expression. However, the majority of islet cells in transgenic mice had expression levels significantly higher than what was observed in islets from wild-type littermates. No hybridization signals above background were seen in in situ hybridization using an SOCS-3 mRNA sense probe in either transgenic or wild-type animals (data not shown). Similar labeling intensities and distribution patterns were seen in transgenic mice from line 7 (data not shown).

Immunohistochemical labeling of pancreatic sections from transgenic or wild-type mice from line 15 with anti-SOCS-3 antibodies as well as with antibodies against different islet hormones is shown in Fig. $1 \mathrm{C}-\mathrm{J}$. Also at the protein level, SOCS-3-positive cells were only detected in transgenic mice (compare Fig. 1E and F). As it was also observed by in situ hybridization, the expression level of the SOCS-3 protein was highly variable in the islets from transgenic mice. The percentage of strongly SOCS-3-positive $\beta$-cells was estimated to be between 10 and $25 \%$, with the remaining $\beta$-cells showing less SOCS-3 staining. Immunohistochemical labeling for markers of $\beta$-cells (insulin; Fig. $1 \mathrm{C}$ and $\mathrm{D}$ ) or non- $\beta$ islet cells (i.e. glucagon-, somatostatin- or pancreatic polypeptideexpressing cells; Fig. $1 \mathrm{G}$ and $\mathrm{H}$ ) revealed no differences between the expression patterns or labeling intensity of these proteins in transgenic mice as compared with wild-type mice. As can be seen from the merged pictures (Fig. 1I and J), SOCS-3 expression was only found in cells also expressing insulin. However, labeling of SOCS-3 protein was seen both in the cytoplasm and in the nucleus of $\beta$-cells. Similar labeling intensities and distribution patterns of SOCS- 3 , insulin and non- $\beta$ cell hormones were seen in pancreatic sections from mice in line 7 (data not shown).

No expression of the RIP-SOCS-3 transgene mRNA was observed in whole brain, hypothalamus, liver, spleen or heart when evaluated by reverse transcriptase PCR (data not shown).

\section{Overexpression of SOCS-3 leads to a decreased $\beta$-cell volume in female transgenic mice}

Since SOCS-3 has been shown to inhibit GH and PRL signaling and since these hormones are known regulators of $\beta$-cell proliferation, we analyzed the relative $\beta$-cell mass as well as $\beta$-cell proliferation in the SOCS-3 transgenic mice. We collected sections for every $200 \mu \mathrm{m}$ throughout pancreata from six male and six female transgenic mice and six male and six female wild-type littermates, all from line 15, and point-counted a section for every second level of the pancreata for morphometric analysis. As can be seen in Fig. 2A, there was no significant difference in $\beta$-cell volume between male and female mice in either group or between male transgenic mice and male wild-type littermates. However, the $\beta$-cell volume of transgenic female mice was reduced by over $30 \%$ when compared with that of wild-type female littermates. In agreement with this observation we found that pancreatic insulin content was also significantly reduced in female transgenic mice compared with wild-type littermates (Fig. 2B). In order to analyze $\beta$-cell proliferation we measured BrdU incorporation into $\beta$-cells from mice given $\mathrm{BrdU}$ in their drinking water overnight. Point-counting morphometry of pancreatic sections from line 15 double immunolabeled for $\mathrm{BrdU}$ and insulin revealed no difference in $\beta$-cell proliferation between wild-type and SOCS-3 transgenic mice (Fig. 2C).

Plasma insulin concentrations were measured in both male and female mice at 6 and 18 weeks of age. No difference in plasma insulin between wild-type and SOCS-3 male transgenic mice was observed (Fig. 3A). In female mice a $20-30 \%$ reduction in plasma insulin levels was observed in the SOCS-3 transgenic mice compared with wild-type mice; however, this difference did not reach statistical significance (Fig. 3B).

\section{Overexpression of SOCS-3 inhibits GH-mediated proliferation of primary $\beta$-cells}

To test whether the decreased $\beta$-cell volume observed in female transgenic mice could be caused by an inhibition of $\mathrm{GH}$-induced $\beta$-cell proliferation by SOCS-3, a $\beta$-cell proliferation assay was performed. Using adenoviral 

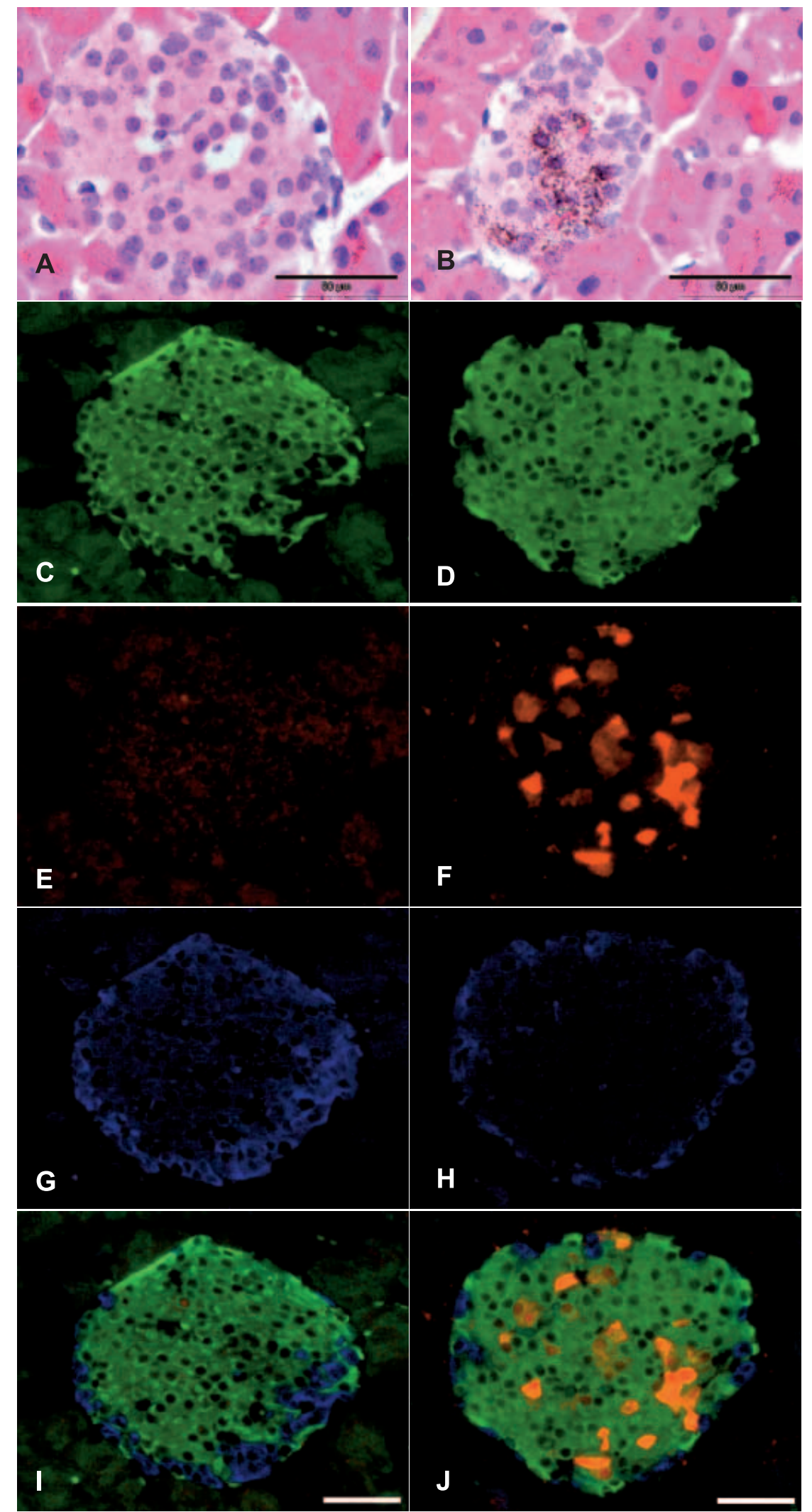

H
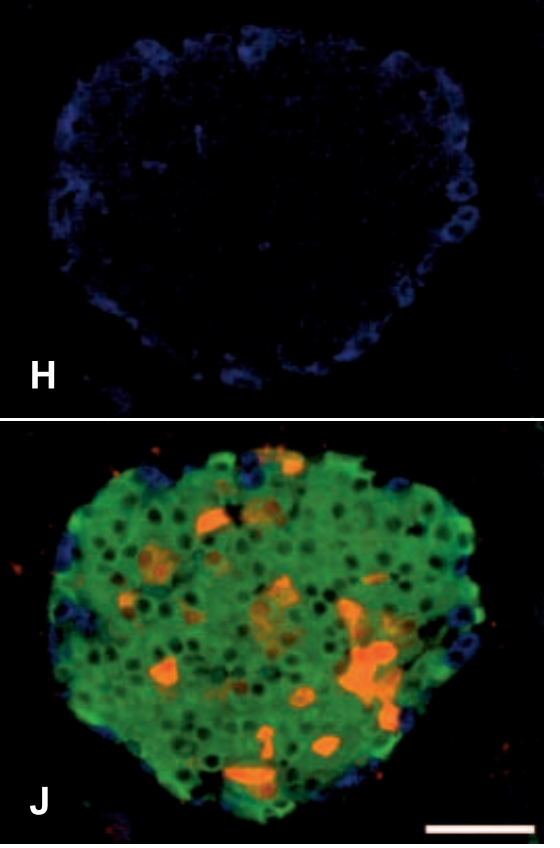
transductions of neonatal rat islet cultures with recombinant adenoviruses expressing various SOCS proteins, followed by stimulation with either GH or GLP-1, we measured the incorporation of BrdU into insulin-producing cells. As can be seen from Fig. 4, expression of SOCS-3 in neonatal rat islets inhibited GH-induced proliferation by about $50 \%$. This effect seems to be specific for SOCS-3 since SOCS-1, SOCS-2 or cytokine-inducible $\mathrm{SH} 2$ containing protein (CIS) expression did not affect GH-induced $\beta$-cell proliferation. Also, the effect of SOCS-3 on $\beta$-cell proliferation appeared to be selective for $\mathrm{GH}$, since no effect of SOCS-3 on GLP-1-stimulated $\beta$-cell proliferation could be observed.

\section{Decreased GH-induced STAT-5 tyrosine phosphorylation in SOCS-3 transgenic islets in vitro}

In order to test whether the expression of SOCS-3 in the $\beta$-cells of the transgenic mice would affect known signaling events induced by GH we examined the tyrosine phosphorylation of STAT-5 by GH in cultured islets from wild-type and SOCS-3 transgenic mice. As can be seen in Fig. 5, GH stimulated the tyrosine phosphorylation of STAT- 5 in islets from wild-type mice following a 20-min exposure to GH. In islets from SOCS-3 transgenic mice this tyrosine phosphorylation was reduced markedly. Quantification of the tyrosine phosphorylation by image analysis revealed a $60-70 \%$ reduction in tyrosine phosphorylation.

\section{SOCS-3 transgenic female mice exhibit enhanced glucose tolerance in an oral glucose-tolerance test}

In order to test whether the expression of SOCS-3 in $\beta$-cells affects glucose metabolism in mice we first measured blood glucose levels after $6 \mathrm{~h}$ fasting in mice from 4 to 24 weeks of age. As can be seen from Fig. 6, no difference in blood glucose levels between transgenic and wild-type mice was observed. Furthermore, no difference in body weights between transgenic and wild-type mice was observed in the same period (data not shown). For a more detailed analysis of glucose metabolism we performed an oral glucose-tolerance test on wild-type and transgenic mice. Following oral glucose administration the blood glucose concentrations were measured every $10 \mathrm{~min}$ for the first hour and every 30 min for an additional hour. As can be seen from Fig. $7 \mathrm{~A}$, no difference in glucose tolerance was observed between male transgenic and wild-type mice. In contrast, the overexpression of SOCS-3 in female mice resulted in an enhanced glucose tolerance, with the blood glucose concentration being significantly lower in transgenic mice between 20 and $90 \mathrm{~min}$ after glucose administration (Fig. 7B).

\section{Discussion}

GH and PRL are known to exert positive effects on $\beta$-cell proliferation and insulin production. We have previously shown that the cytokine-inhibitory protein SOCS-3 is able to inhibit and thereby regulate these effects in vitro (Rønn et al. 2002). However, the in vivo effect of SOCS-3 on the actions of GH/PRL in $\beta$-cells still remains to be described.

In the present study we generated two lines of transgenic mice overexpressing SOCS-3 in pancreatic $\beta$-cells in order to analyze in vivo effects of SOCS-3 in these cells. Overexpression of SOCS-3 could be detected at both the mRNA and protein levels in $\beta$-cells of transgenic mice. However, the expression levels of both SOCS-3 mRNA and protein varied highly between individual islet cells, possibly reflecting the fact that pancreatic $\beta$-cells consist of a heterogenic pool of cells that exhibit intercellular differences in the rates of glucose-induced insulin synthesis (Pipeleers et al. 1994). Unlike insulin, SOCS-3 mRNA has been shown to have a short half-life (Hilton 1999). Thus the relatively small fraction of insulin-containing cells, which also had strong expression of SOCS-3, may reflect the number of $\beta$-cells that actively transcribed and synthesized insulin/RIPSOCS-3 around the time of death of the animals. Despite the large variation in expression level of the SOCS-3 transgene in $\beta$-cells we were able to show a reduced activation of STAT- 5 by GH in islets from SOCS-3 transgenic mice. We cannot at present distinguish between an overall reduction in $\mathrm{GH}$ signaling in all $\beta$-cells or a marked reduction in only the $\beta$-cells showing the highest expression levels of the SOCS-3 transgene. Further studies using immunohistochemical techniques to evaluate $\mathrm{GH}$ signaling will be needed to address this issue.

\footnotetext{
Figure 1 In situ hybridization with SOCS-3 mRNA antisense probes and expression and co-localization of SOCS-3 protein and different islet hormones in wild-type and transgenic mice. In situ hybridization with SOCS-3 mRNA antisense probes or triple-fluorescence labeling of SOCS-3 and different islet hormones were performed on pancreatic sections from wild-type (A, C, E, $\mathrm{G}$ and $\mathrm{I}$ ) or transgenic mice (B, D, F, H and J). (A, B) In situ hybridization. SOCS-3 mRNA expression is seen as dark silver staining of islet cells in (B). Paraffin sections counterstained with hematoxylin and eosin. (C, D) Insulin-labeled islets (green; FITC signal). $(E, F)$ SOCS-3-labeled islets. SOCS-3 staining is only seen in (F) (red; Texas Red signal). (G, H) Labeling against non- $\beta$-cell hormones (glucagons, pancreatic polypeptide and somatostatin; blue; AMCA signal). Sections were photographed using single exposure and different filters $(\mathrm{C}-\mathrm{H})$ and then merged digitally $(\mathrm{I}$ and $\mathrm{J})$. Only data from transgenic mouse line 15 are shown. All scale bars, $50 \mu \mathrm{m}$.
} 
Expression of SOCS-3 protein was found both in the cytoplasm and in the nuclei of $\beta$-cells in transgenic mice (Fig. $1 \mathrm{~F}$ and J). At present SOCS proteins are believed to exert their inhibitory function in the cytoplasm (Krebs \&

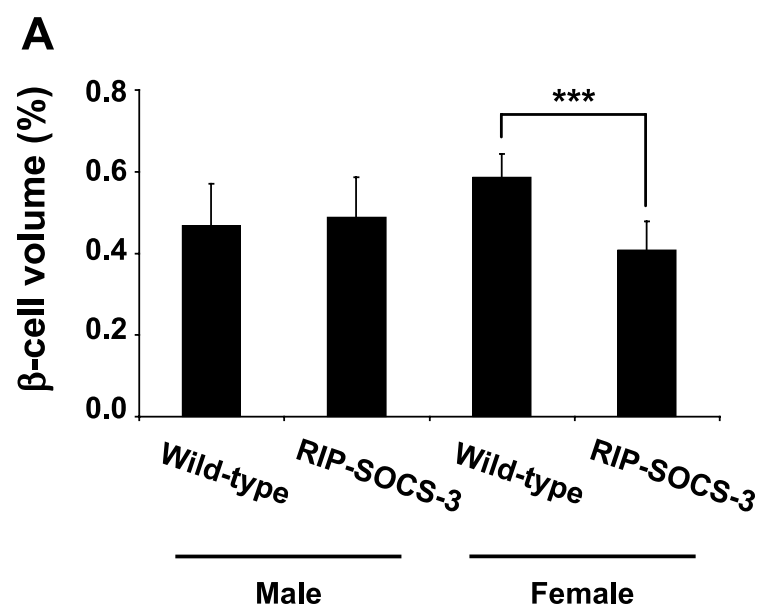

B

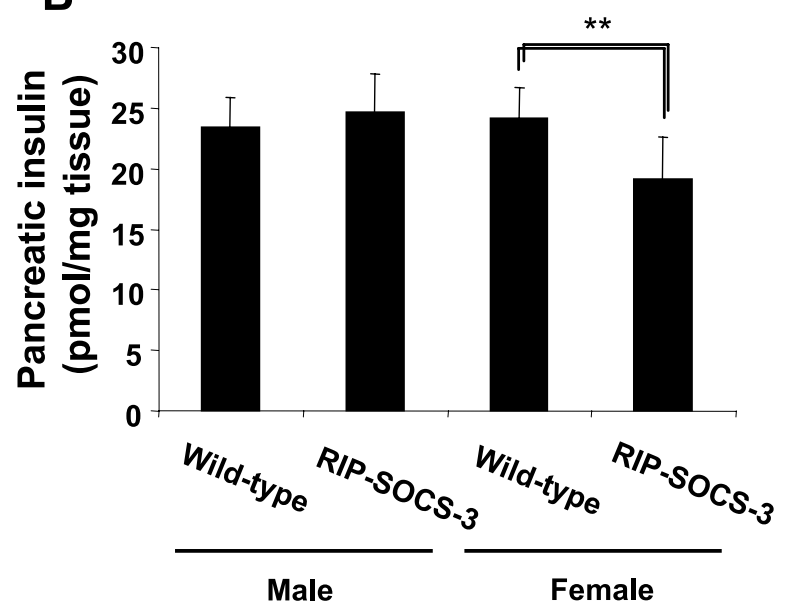

C

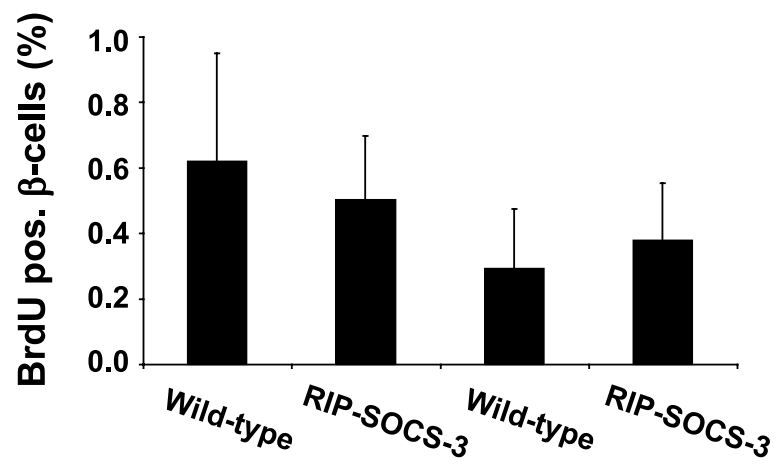

Male
Female
Hilton 2001). Whether the observed nuclear expression of SOCS-3 is a cellular mis-direction of the protein related to transgenic overexpression or whether SOCS-3 also enters the nucleus under more normal circumstances is not clear at the moment. Nuclear translocation of a wide range of cytokine receptor complexes, including the cytokine, its receptor and related JAK kinases, as well as nuclear translocation of phosphatases such as SHP-1 is well documented (reviewed by Mertani et al. 1999) and from that perspective it is not surprising that also SOCS proteins could be translocated to the nucleus. However, the biological relevance of such a translocation needs further investigation.

Since SOCS-3 has been shown to inhibit GH (Adams et al. 1998, Ram \& Waxman 1999) and PRL (Helman et al. 1998, Tomic et al. 1999) signaling and since these hormones are known regulators of $\beta$-cell proliferation (Nielsen 1985, Nielsen et al. 1992, Brelje et al. 1993) we measured the relative $\beta$-cell volume and $\beta$-cell proliferation in SOCS-3 transgenic mice by pointcounting morphometry. As illustrated in Fig. 2A, the $\beta$-cell volume of transgenic female mice was reduced by over $30 \%$ compared with the $\beta$-cell volume in wild-type female mice, whereas no differences in $\beta$-cell volume between male and female mice or between male wildtype and transgenic mice were found. The significant difference in $\beta$-cell volume between female wild-type and transgenic mice partly reflects the fact that the $\beta$-cell volume of the wild-type female mice was relatively large compared with the $\beta$-cell volume in the male mice. An observation like that is not unique to this study. Thus a higher amount of pancreatic insulin in females has been reported both for rats and humans (reviewed by Bonnevie-Nielsen 1986), and it has been shown that treatment with streptozotocin (which lead to specific destruction of $\beta$-cells and thereby induction of diabetes) has a more dramatic effect on male than on female rats (Bell et al. 1994).

The pronounced reduced $\beta$-cell volume in transgenic female mice supports the hypothesis that an overexpression of SOCS-3 may inhibit GH- or PRLstimulated $\beta$-cell proliferation in transgenic animals. However, at the age when we performed point-counting

Figure $2 \beta$-Cell volume, pancreatic insulin content and BrdU-positive $\beta$-cells in transgenic mice and wild-type littermates. (A) $\beta$-Cell volume was measured by point-counting morphometry. Mean \pm S.D. $\beta$-cell volume (\%) per group is shown; $n=6$ in all groups. Statistical significance was assessed using Student's $t$-test. ${ }^{\star * *} P \leq 0.001$ (female wild-type versus female transgenic). (B) Pancreatic insulin content was measured by RIA in acetic acid extracted pancreas from male and female mice at the age of 29 weeks. Results are given as mean \pm S.D. for $6-11$ mice in each group. ${ }^{* \star} P<0.01$. (C) Fraction of BrdU-positive $\beta$-cells was measured by point-counting morphometry. Mean \pm S.D. BrdU-positive $\beta$-cells (\%) is shown; $n=6$ in all groups. 
A
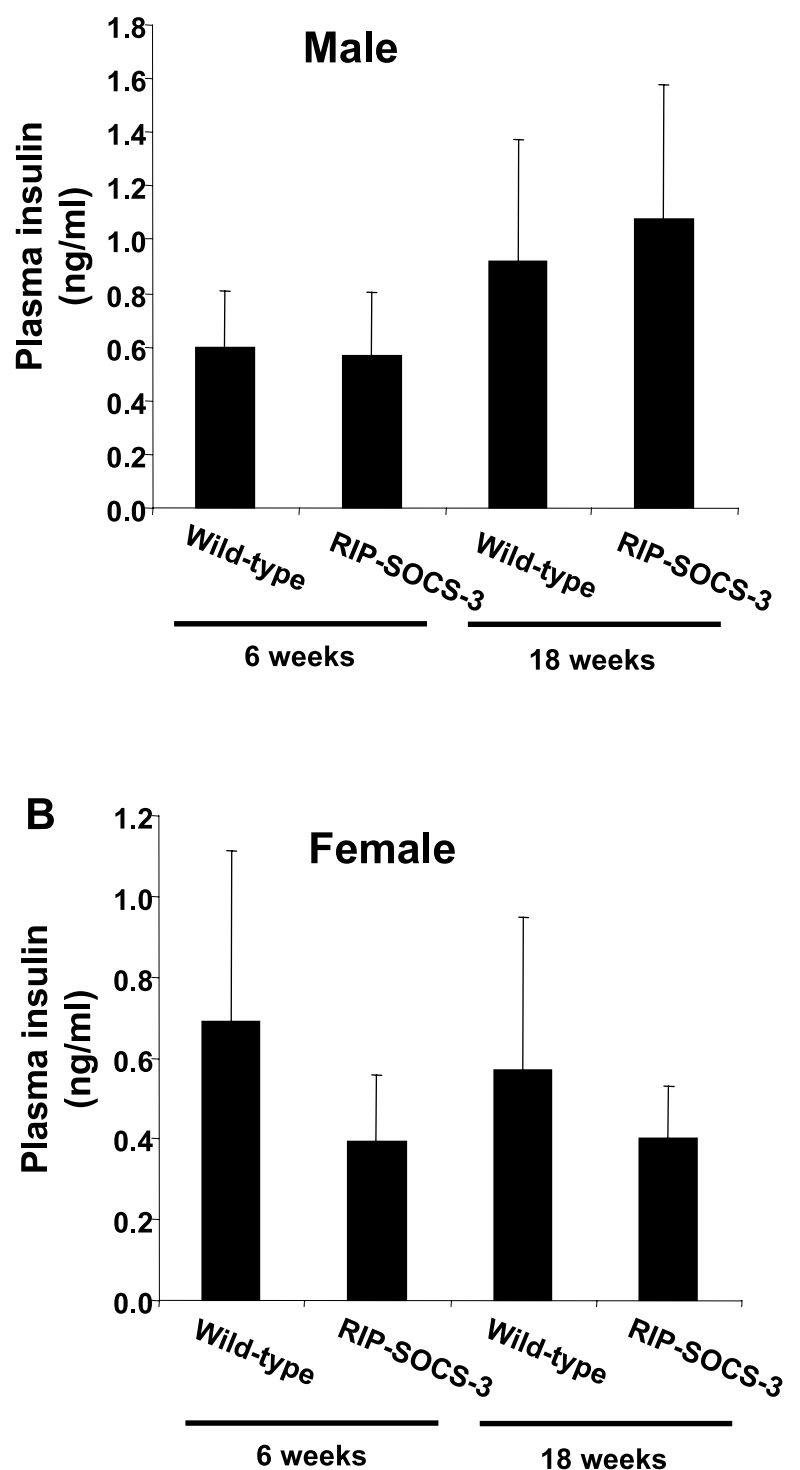

Figure 3 Plasma insulin. Insulin concentrations were measured in plasma samples from male (A) or female (B) mice at the age of 6 or 18 weeks. The results are presented as means \pm S.D. for 7-10 mice in each group.

morphometry (i.e. 2 months), no difference in the amount of proliferating $\beta$-cells was observed in any of the groups (Fig. 2C), indicating that the inhibition of growth factors like GH or PRL may have happened at an earlier stage in the life of these mice. The period with the highest level of proliferation of islet cells in rodents is during the last few days of gestation, continuing into the first few days after gestation (Kaung 1994, Finegood et al. 1995). Furthermore, the effect of PRL or GH on proliferation is more pronounced in neonatal islets than in adult islets (Brelje \& Sorenson 1991). Thus an

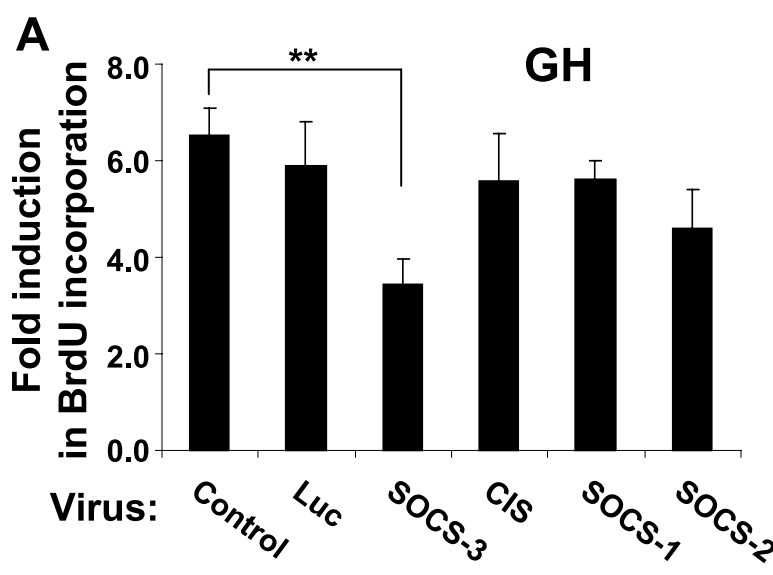

B

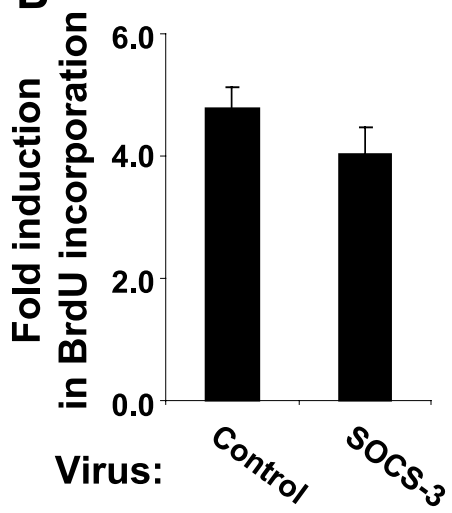

GLP-1

Figure 4 Effect of SOCS-3 on GH- or GLP-1-induced BrdU incorporation into primary $\beta$-cells. Neonatal islet monolayer cultures were transduced with the indicated adenoviral SOCS or luciferase (luc) encoding-constructs $\left(5 \times 10^{8} \mathrm{pfu} / \mathrm{ml}\right)$ and the following day stimulated with either $(A) \mathrm{hGH}(0.5 \mu \mathrm{g} / \mathrm{ml})$ or (B) GLP-1 (100 nM). After an additional 24-h period BrdU $(10 \mu \mathrm{M})$ was added and $20 \mathrm{~h}$ later the cells were fixed and double-immunostained for BrdU and insulin expression. A total of 1000-1500 cells were counted in each preparation and the fractions of BrdU-positive $\beta$-cells were calculated. The results are expressed as fold induction between non-stimulated and hGH- or GLP-1-stimulated samples. Mean \pm S.E.M. BrdU-positive cells (\%) are shown; $n=3-6$. Statistical significance was assessed using Student's $t$-test; ${ }^{\star \star} P \leq 0.01$ (control cells versus SOCS-3 construct-transduced cells).

inhibition of GH or PRL signaling around the time of birth of the animals could explain why a smaller $\beta$-cell volume is found in adult mice even though no differences in $\beta$-cell proliferation could be found in these animals at time of death. As can be seen from Fig. 4, SOCS-3 is able to inhibit hGH induced proliferation, which activates both the $\mathrm{GH}$ and PRL receptors in rodents (Møldrup et al. 1990). This effect seems to be selective since overexpression of SOCS-3 has no effect on GLP-1-induced proliferation, which is not induced via the JAK/STAT pathway (Buteau et al. 2001). Furthermore, this effect also seems to be specific for 


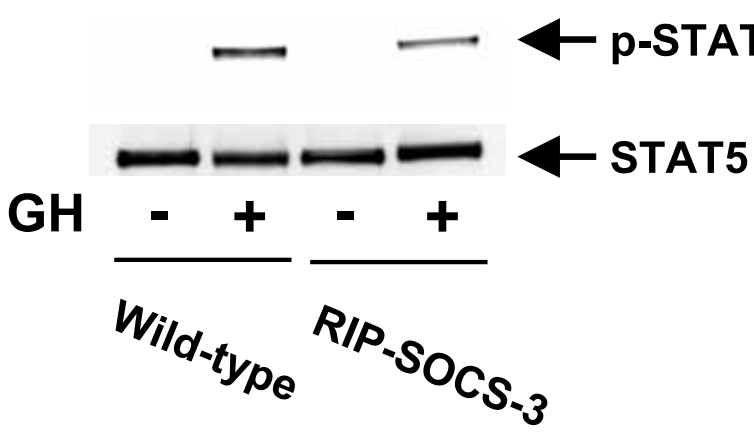

Figure $5 \mathrm{GH}$-induced STAT-5 phosphorylation in transgenic and wild-type islets. Pancreatic islets were isolated from wild-type and RIP-SOCS-3 transgenic mice and stimulated with $0.5 \mu \mathrm{g} / \mathrm{ml} \mathrm{hGH}$ for $20 \mathrm{~min}$. Cell lysates were separated by SDS/PAGE and STAT-5 tyrosine phophorylation (p-STAT-5) was investigated by Western blotting. Subsequently the membranes were stripped and incubated with an antibody recognizing total STAT-5. The result shown is representative of two experiments.

SOCS-3, since SOCS-1, SOCS-2 or CIS expression did not affect hGH-induced $\beta$-cell proliferation. Both SOCS-1 and -3 are known to exert their inhibitory action at the level of JAK-2 (Hansen et al. 1999, Nicholson et al. 1999, Ram \& Waxman 1999, Dif et al. 2001) and the finding that only SOCS-3 inhibited GH-induced proliferation in the primary $\beta$-cells may reflect that the effect of SOCS proteins are very cell- and tissue-specific. Further studies in pregnant transgenic mice, where there is a pregnancy- associated increase in PRL, may reveal further information on the role of SOCS-3 in GH and PRL signaling in islets.

The reason why the $\beta$-cell volume is affected in female transgenic mice but not in male transgenic mice is not known at present. In humans, evidence that estrogen negatively regulates $\mathrm{GH}$ action in certain cases does exist (reviewed by Leung et al. 2003), and recently it has been reported that this inhibitory effect of estrogen on $\mathrm{GH}$ signaling may be mediated by SOCS-2 (Leung et al. 2003). One could speculate that the negative effects of SOCS-2 (induced by estrogen) and SOCS-3 (overexpressed by the transgene) on GH/PRL signaling in pancreatic $\beta$-cells in female mice in combination exert an effect of SOCS-3 on GH/PRL signaling, which is significant in the female but not the male mice.

Even though the $\beta$-cell volume and the pancreatic insulin content in female transgenic mice are reduced it could be speculated that only insulin synthesis at the transcriptional level and $\beta$-cell proliferation are affected and that insulin storage and glucose-stimulated secretion could be unaffected, leading to the hypothesis that the remaining $69 \%$ of the $\beta$-cell mass is sufficient to maintain glucose homeostasis, since it has been shown that rodents can maintain glucose homeostasis even if their $\beta$-cell mass is reduced by $40-90 \%$ (Brockenbrough

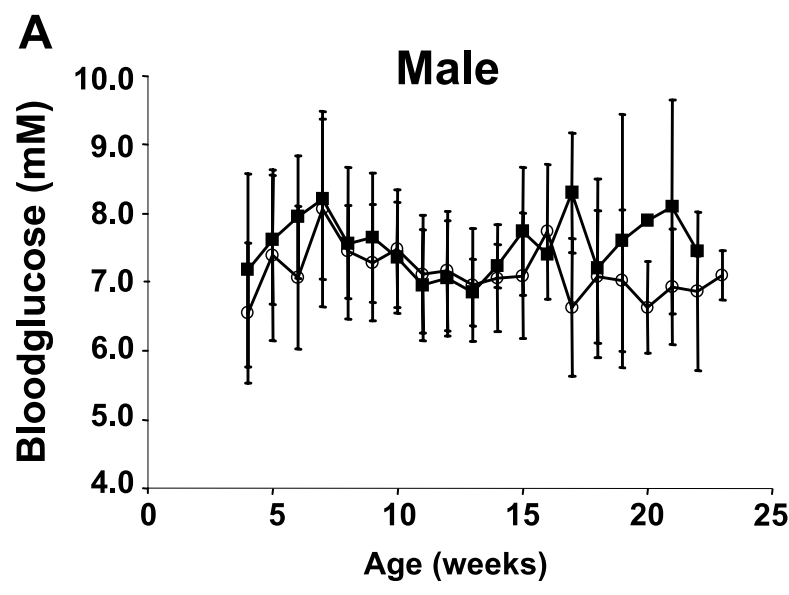

$\rightarrow$ RIP-SOCS-3 $\neg$-Wild-type

B

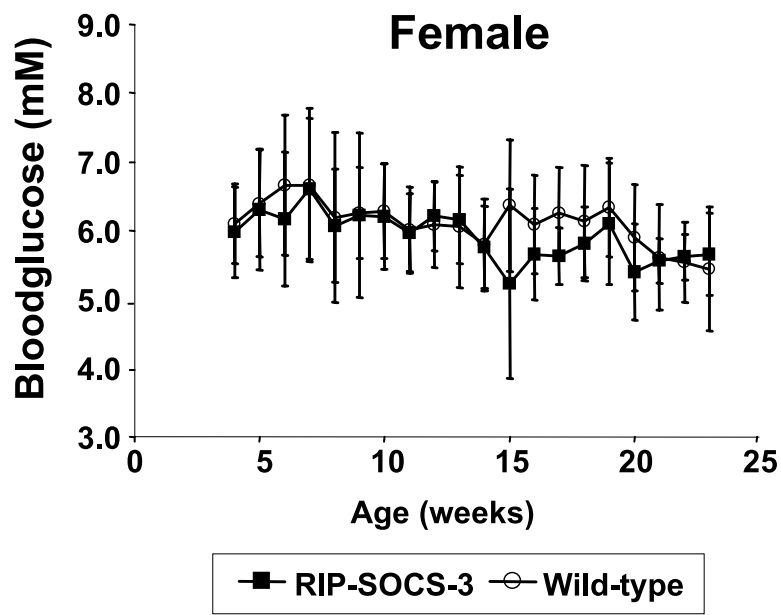

Figure 6 Mean blood glucose. Blood glucose was measured once a week in a drop of tail blood after $6 \mathrm{~h}$ fasting. Accumulated data for lines 7 and 15 are shown. (A) Male mice: $n=12-38$ for weeks $4-13$ and $n=2-17$ for weeks $14-23$. (B) Female mice: $n=11-40$ for weeks $4-15)$ and $n=7-18$ for weeks $16-23$. The results are presented as means \pm S.D.

et al. 1988, Lee et al. 1989). Accordingly, as can be seen from Fig. 6, no differences were seen between wild-type and trangenic male or female mice in fasting blood glucose levels. Given the reduced $\beta$-cell volume in female transgenic mice it could be expected that if the ability of these mice to normalize their blood glucose was altered compared with wild-type female mice, these mice would have a reduced ability to normalize the blood glucose in an oral glucose-tolerance test. As can be seen from Fig. 7B this was not the case. On the contrary, female transgenic mice were better at clearing glucose from the blood than their wild-type littermates. The reason for this must be either that the $\beta$-cells in transgenic 


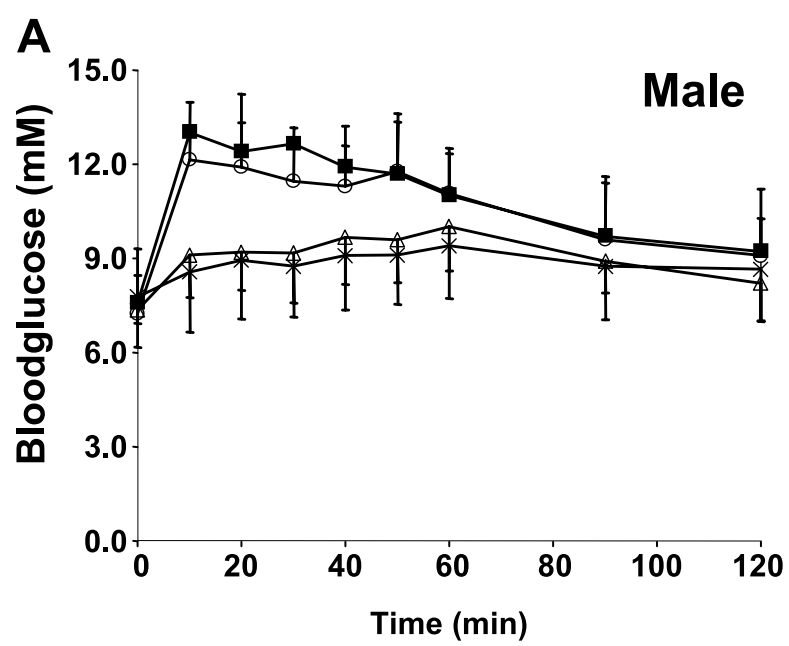

\section{$\rightarrow$-Wildtype, glucose - -RIP-SOCS-3, glucose *-Wildtype, water $\triangle$ RIP-SOCS-3, water}

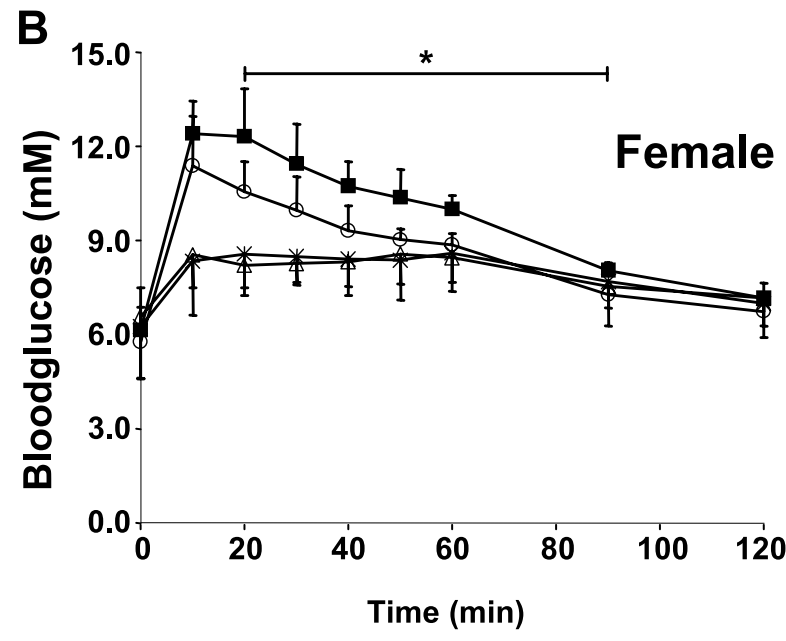

$\rightarrow$ Wildtype, glucose $\neg$ RIP-SOCS-3, glucose * Wildtype, water

RIP-SOCS-3, water

Figure 7 Oral glucose-tolerance test in male $(A)$ and female (B) mice from line 15. Oral glucose-tolerance test (glucose load, $2 \mathrm{~g} / \mathrm{kg}$ ) or administration of an equivalent volume of water, were performed on six transgenic mice and six wild-type littermates for each graph. Both types of mouse were challenged twice with glucose and water. The results are presented as means \pm S.D Statistical significance was assessed using the Wilcoxon two-sample test; ${ }^{*} P \leq 0.05$ (glucose-challenged wild-type versus glucose-challenged transgenic female mice).

female mice are more glucose-sensitive and secrete more insulin per cell than $\beta$-cells in wild-type females or that the peripheral tissues in transgenic female mice are more insulin-sensitive than in wild-type littermates.
Several other hormones and cytokines that affect $\beta$-cell function may also have been modulated by overexpression of SOCS-3. Leptin has been reported to inhibit insulin gene transcription and secretion (Fehmann et al. 1997, Kulkarni et al. 1997, Seufert et al. 1999) and recently SOCS-3 has been shown to be induced by leptin and inhibit leptin-mediated JAK/ STAT signaling in INS- 1 pancreatic $\beta$-cells and in isolated pancreatic islets of $o b / o b$ mice (Seufert 2004). Also, SOCS-3 has been shown to inhibit insulin signaling in several cell types (Emanuelli et al. 2001, Ueki et al. 2004) and insulin is known to affect $\beta$-cell function and to enhance insulin gene transcription and release and to inhibit $\beta$-cell apoptosis (Rakatzi et al. 2003). Finally, cytokines such as interferon- $\gamma$, interleukins 1 and 6 and tumor necrosis factor- $\alpha$ also affect $\beta$-cells (Eizirik et al. 1996, Mandrup-Poulsen 1996, Eizirik \& MandrupPoulsen 2001), and their actions are known to be inhibited by SOCS-3 (Karlsen et al. 2001). Thus an explanation for the enhanced glucose tolerance seen in the female transgenic mice could be that overexpression of SOCS-3 in the $\beta$-cells of these animals inhibits signaling by several hormones or cytokines, leading to an enhanced insulin secretion by the $\beta$-cells when stimulated by glucose (i.e. they become more glucosesensitive). However, preliminary in vitro experiments showed no difference in basal and glucose-induced insulin release between wild-type and RIP-SOCS-3 islets (data not shown), indicating that increased insulin release from RIP-SOCS-3 transgenic islets might not explain the increased glucose tolerance observed in female transgenic mice. Thus further studies are needed to clarify this matter.

In summary, in this study we generated transgenic mice overexpressing SOCS-3 specifically in the pancreatic $\beta$-cells. No differences in fasting blood glucose could be detected in transgenic animals compared with wild-type littermates; however, the female transgenic mice were proved to have reduced $\beta$-cell volume. This reduction may be related to diminished islet cell proliferation due to inhibited GH/PRL signaling at some point in the life of these animals, as indicated by the fact that SOCS-3 virally transduced into neonatal rat islets could inhibit GH-induced proliferation. Furthermore, even though the female transgenic mice had a reduced $\beta$-cell volume they also exhibited enhanced glucose clearance as a result of glucose-stimulated insulin secretion in an oral glucose-tolerance test. It is speculated that the reason for this could be a SOCS3-mediated inhibition of several different signaling pathways in the $\beta$-cells that in combination could lead to enhanced insulin secretion by the $\beta$-cells when stimulated by glucose, but further studies are needed to clarify this matter. In addition, it is not known if or to what extent an overexpression of SOCS-3 may influence the level of other SOCS proteins in the pancreatic 
$\beta$-cells. Understanding the way SOCS-3 affects signaling pathways of the $\beta$-cell may add important knowledge of expansion and differentiation of these cells, which eventually could lead to development of new treatment strategies for diabetes or even prevention of this disease. Thus it will be interesting in the future to try to dissect the effects of SOCS-3 on the different signal transduction pathways of the $\beta$-cell.

\section{Acknowledgements}

We thank Susanne Primdahl, Winnie Listov-Saabye and Helle Francker Petersen for excellent technical assistance.

\section{Funding}

K L was supported by the Danish Research Academy, S G R was supported by a $\mathrm{PhD}$ fellowship from University of Copenhagen, H R was supported by the Danish Academy for the Technical Sciences and J A H was supported by a grant from the Danish Cancer Research Foundation. The work was also supported by Juvenile Diabetes Foundation International (grant no. 1-2001-706). The authors declare that there is no conflict of interest that would prejudice the impartiality of this scientific work.

\section{References}

Adams TE, Hansen JA, Starr R, Nicola NA, Hilton DJ \& Billestrup N 1998 Growth hormone preferentially induces the rapid, transient expression of SOCS-3, a novel inhibitor of cytokine receptor signaling. Fournal of Biological Chemistry 273 1285-1287.

Argetsinger LS \& Carter-Su C 1996 Mechanism of signaling by growth hormone receptor. Physiological Reviews 76 1089-1107.

Bell RC, Khurana M, Ryan EA \& Finegood DT 1994 Gender differences in the metabolic response to graded numbers of transplanted islets of Langerhans. Endocrinology 135 2681-2687.

Bonnevie-Nielsen V 1980 Experimental diets affect pancreatic insulin and glucagon differently in male and female mice. Metabolism: Clinical and Experimental 29 386-391.

Bonnevie-Nielsen V 1986 The endocrine pancreas: aspects of beta-cell function in relation to morphology, insulin secretion and insulin content. Scandinavian Fournal of Clinical and Laboratory Investigation 183 Suppl 1-47.

Brelje TC \& Sorenson RL 1991 Role of prolactin versus growth hormone on islet B-cell proliferation in vitro: implications for pregnancy. Endocrinology 128 45-57.

Brelje TC, Scharp DW, Lacy PE, Ogren L, Talamantes F, Robertson M, Friesen HG \& Sorenson RL 1993 Effect of homologous placental lactogens, prolactins, and growth hormones on islet B-cell division and insulin secretion in rat, mouse, and human islets: implication for placental lactogen regulation of islet function during pregnancy. Endocrinology 132 879-887.

Brockenbrough JS, Weir GC \& Bonner-Weir S 1988 Discordance of exocrine and endocrine growth after $90 \%$ pancreatectomy in rats. Diabetes 37 232-236.
Buteau J, Foisy S, Rhodes CJ, Carpenter L, Biden TJ \& Prentki M 2001 Protein kinase Czeta activation mediates glucagon-like peptide-1- induced pancreatic beta-cell proliferation. Diabetes $\mathbf{5 0}$ 2237-2243.

Chow JC, Ling PR, Qu Z, Laviola L, Ciccarone A, Bistrian BR \& Smith RJ 1996 Growth hormone stimulates tyrosine phosphorylation of JAK2 and STAT5, but not insulin receptor substrate-1 or SHC proteins in liver and skeletal muscle of normal rats in vivo. Endocrinology 137 2880-2886.

Dif F, Saunier E, Demeneix B, Kelly PA \& Edery M 2001 Cytokineinducible SH2-containing protein suppresses PRL signaling by binding the PRL receptor. Endocrinology 142 5286-5293.

Eizirik DL \& Mandrup-Poulsen T 2001 A choice of death-the signal-transduction of immune-mediated beta-cell apoptosis. Diabetologia 44 2115-2133.

Eizirik DL, Flodstrøm M, Karlsen AE \& Welsh N 1996 The harmony of the spheres: inducible nitric oxide synthase and related genes in pancreatic beta cells. Diabetologia 39 875-890.

Emanuelli B, Peraldi P, Filloux C, Chavey C, Freidinger K, Hilton DJ, Hotamisligil GS \& Van Obberghen E 2001 SOCS-3 inhibits insulin signaling and is up-regulated in response to tumor necrosis factor-alpha in the adipose tissue of obese mice. Fournal of Biological Chemistry 276 47944-47949.

Endo TA, Masuhara M, Yokouchi M, Suzuki R, Sakamoto H, Mitsui K, Matsumoto A, Tanimura S, Ohtsubo M, Misawa $\mathrm{H}$ et al. 1997 A new protein containing an SH2 domain that inhibits JAK kinases. Nature 387 921-924.

Fehmann HC, Berghofer P, Brandhorst D, Brandhorst H, Hering B, Bretzel RG \& Goke B 1997 Leptin inhibition of insulin secretion from isolated human islets. Acta Diabetologia 34 249-252.

Finegood DT, Scaglia L \& Bonner-Weir S 1995 Dynamics of beta-cell mass in the growing rat pancreas. Estimation with a simple mathematical model. Diabetes 44 249-256.

Freemark M, Avril I, Fleenor D, Driscoll P, Petro A, Opara E, Kendall W, Oden J, Bridges S, Binart N et al. 2002 Targeted deletion of the PRL receptor: effects on islet development, insulin production, and glucose tolerance. Endocrinology 143 1378-1385.

Friedrichsen BN, Galsgaard ED, Nielsen JH \& Møldrup A 2001 Growth hormone- and prolactin-induced proliferation of insulinoma cells, INS-1 depends on activation of STAT5 (signal transducer and activator of transcription 5). Molecular Endocrinology 15 136-148.

Friedrichsen BN, Richter HE, Hansen JA, Rhodes CJ, Nielsen JH, Billestrup N \& Møldrup A 2003 Signal transducer and activator of transcription 5 activation is sufficient to drive transcriptional induction of cyclin D2 gene and proliferation of rat pancreatic beta-cells. Molecular Endocrinology 17 945-958.

Galsgaard ED, Gouilleux F, Groner B, Serup P, Nielsen JH \& Billestrup N 1996 Identification of a growth hormone-responsive STAT5-binding element in the rat insulin 1 gene. Molecular Endocrinology 10 652-660.

Galsgaard ED, Friedrichsen BN, Nielsen JH \& Møldrup A 2001 Expression of dominant-negative STAT5 inhibits growth hormone- and prolactin-induced proliferation of insulin-producing cells. Diabetes $\mathbf{5 0}$ Suppl 1 S40-S41.

Hansen JA, Lindberg K, Hilton DJ, Nielsen JH \& Billestrup N 1999 Mechanism of inhibition of growth hormone receptor signaling by suppressor of cytokine signaling proteins. Molecular Endocrinology 13 $1832-1843$

Helman D, Sandowski Y, Cohen Y, Matsumoto A, Yoshimura A, Merchav S \& Gertler A 1998 Cytokine-inducible SH2 protein (CIS3) and JAK2 binding protein (JAB) abolish prolactin receptor-mediated STAT5 signaling. FEBS Letters 441 287-291.

Hilton DJ 1999 Negative regulators of cytokine signal transduction. Cellular and Molecular Life Sciences 55 1568-1577.

Karlsson O, Edlund T, Moss JB, Rutter WJ \& Walker MD 1987 A mutational analysis of the insulin gene transcription control 
region: expression in beta cells is dependent on two related sequences within the enhancer. PNAS 84 8819-8823.

Karlsen AE, Rønn SG, Lindberg K, Johannesen J, Galsgaard ED, Pociot F, Nielsen JH, Mandrup-Poulsen T, Nerup J \& Billestrup N 2001 Suppressor of cytokine signaling 3 (SOCS-3) protects beta- cells against interleukin-1 beta- and interferongamma-mediated toxicity. PNAS 98 12191-12196.

Kaung HLC 1994 Growth dynamics of pancreatic-islet cell-populations during fetal and neonatal development of the rat. Developmental Dynamics 200 163-175.

Krebs DL \& Hilton DJ 2001 SOCS proteins: negative regulators of cytokine signaling. Stem Cells 19 378-387.

Kulkarni RN, Wang ZL, Wang RM, Hurley JD, Smith DM, Ghatei MA, Withers DJ, Gardiner JV, Bailey CJ \& Bloom SR 1997 Leptin rapidly suppresses insulin release from insulinoma cells, rat and human islets and, in vivo, in mice. Fournal of Clinical Investigation 100 2729-2736.

Lee HC, Bonner-Weir S, Weir GC \& Leahy JL 1989 Compensatory adaptation to partial pancreatectomy in the rat. Endocrinology $\mathbf{1 2 4}$ 1571-1575.

Leung KC, Doyle N, Ballesteros M, Sjogren K, Watts CKW, Low TH, Leong GM, Ross RJM \& Ho KKY 2003 Estrogen inhibits GH signaling by suppressing GH-induced JAK2 phosphorylation, an effect mediated by SOCS-2. PNAS 100 1016-1021.

Magrangeas F, Boisteau O, Denis S, Jacques Y \& Minvielle S 2001 Negative cross-talk between interleukin-3 and interleukin-11 is mediated by suppressor of cytokine signalling-3 (SOCS-3). Biochemical fournal $353223-230$.

Mandrup-Poulsen T 1996 The role of interleukin-1 in the pathogenesis off IDDM. Diabetologia 39 1005-1029.

Mertani HC, Morel G \& Lobie PE 1999 Cytoplasmic and nuclear cytokine receptor complexes. Vitamins and Hormones; Advances in Research and Applications $\mathbf{5 7} 79-121$.

Møldrup A, Billestrup N \& Nielsen JH 1990 Rat insulinoma cells express both a $115-\mathrm{kDa}$ growth hormone receptor and a $95-\mathrm{kDa}$ prolactin receptor structurally related to the hepatic receptors. Fournal of Biological Chemistry 265 8686-8690.

Naka T, Narazaki M, Hirata M, Matsumoto T, Minamoto S, Aono A, Nishimoto N, Kajita T, Taga T, Yoshizaki K et al. 1997 Structure and function of a new STAT-induced STAT inhibitor. Nature 387 924-929.

Nicholson SE, Willson TA, Farley A, Starr R, Zhang JG, Baca M, Alexander WS, Metcalf D, Hilton DJ \& Nicola NA 1999 Mutational analyses of the SOCS proteins suggest a dual domain requirement but distinct mechanisms for inhibition of LIF and IL-6 signal transduction. EMBO fournal 18 375-385.

Nielsen JH 1982 Effects of growth hormone, prolactin, and placental lactogen on insulin content and release, and deoxyribonucleic acid synthesis in cultured pancreatic islets. Endocrinology $110600-606$.

Nielsen JH 1985 Growth and function of the pancreatic beta cell in vitro: effects of glucose, hormones and serum factors on mouse, rat and human pancreatic islets in organ culture. Acta Endocrinolica Suppl (Copenhagen) 266 1-39.

Nielsen JH, Linde S, Welinder BS, Billestrup N \& Madsen OD 1989 Growth hormone is a growth factor for the differentiated pancreatic beta-cell. Molecular Endocrinology 3 165-173.

Nielsen JH, Møldrup A, Billestrup N, Petersen ED, Allevato G \& Stahl M 1992 The role of growth hormone and prolactin in beta cell growth and regeneration. Advances in Experimental Medicine and Biology 321 9-17.

Pezet A, Favre H, Kelly PA \& Edery M 1999 Inhibition and restoration of prolactin signal transduction by suppressors of cytokine signaling. Fournal of Biological Chemistry 274 24497-24502.

Pipeleers D, Kiekens R, Ling Z, Wilikens A \& Schuit F 1994 Physiologic relevance of heterogeneity in the pancreatic beta-cell population. Diabetologia 37 Suppl 2 S57-S64.

Rakatzi I, Seipke G \& Eckel J 2003 [LysB3, GluB29] insulin: a novel insulin analog with enhanced beta-cell protective action. Biochemical and Biophysical Research Communications 310 852-859.

Ram PA \& Waxman DJ 1999 SOCS/CIS protein inhibition of growth hormone-stimulated STAT5 signaling by multiple mechanisms. Fournal of Biological Chemistry 274 35553-35561.

Rønn SG, Hansen JA, Lindberg K, Karlsen AE \& Billestrup N 2002 The effect of suppressor of cytokine signaling 3 on GH signaling in beta-cells. Molecular Endocrinology $162124-2134$.

Schmitz J, Weissenbach M, Haan S, Heinrich PC \& Schaper F 2000 SOCS3 exerts its inhibitory function on interleukin-6 signal transduction through the SHP2 recruitment site of gp130. Fournal of Biological Chemistry 275 12848-12856.

Seufert J 2004 Leptin effects on pancreatic beta-cell gene expression and function. Diabetes 53 Suppl 1 S152-S158.

Seufert J, Kieffer TJ \& Habener JF 1999 Leptin inhibits insulin gene transcription and reverses hyperinsulinemia in leptin-deficient ob/ob mice. PNAS $96674-679$.

Smit LS, Meyer DJ, Billestrup N, Norstedt G, Schwartz J \& Carter-Su C 1996 The role of the growth hormone $(\mathrm{GH})$ receptor and JAK 1 and JAK2 kinases in the activation of Stats 1, 3, and 5 by GH. Molecular Endocrinology 10 519-533.

Sorenson RL \& Brelje TC 1997 Adaptation of islets of Langerhans to pregnancy: beta-cell growth, enhanced insulin secretion and the role of lactogenic hormones. Hormone and Metabolic Research 29 301-307.

Starr R, Willson TA, Viney EM, Murray LJ, Rayner JR, Jenkins BJ, Gonda TJ, Alexander WS, Metcalf D, Nicola NA \& Hilton DJ 1997 A family of cytokine-inducible inhibitors of signalling. Nature 387 917-921.

Tomic S, Chughtai N \& Ali S 1999 SOCS-1, -2, -3: selective targets and functions downstream of the prolactin receptor. Molecular and Cellular Endocrinology 158 45-54.

Ueki K, Kondo T \& Kahn CR 2004 Suppressor of cytokine signaling 1 (SOCS-1) and SOCS-3 cause insulin resistance through inhibition of tyrosine phosphorylation of insulin receptor substrate proteins by discrete mechanisms. Molecular and Cellular Biology 24 5434-5446.

Vasavada RC, Garcia-Ocana A, Zawalich WS, Sorenson RL, Dann P, Syed M, Ogren L, Talamantes F \& Stewart AF 2000 Targeted expression of placental lactogen in the beta cells of transgenic mice results in beta cell proliferation, islet mass augmentation, and hypoglycemia. Fournal of Biological Chemistry 275 15399-15406.

Wu XW, Herndon DN \& Wolf SE 2003 Growth hormone down-regulation of interleukin-1 beta and interleukin- 6 induced acute phase protein gene expression is associated with increased gene expression of suppressor of cytokine signal-3. Shock 19 $314-320$.

Received 22 June 2005 Accepted 1 July 2005 